\title{
In Vitro Phytobiocidal Management of Root Rot Fusarium solani (Mart.) Sacc of Abelmoschus esculentus (L.)
}

\author{
Kausar Mumtaz ${ }^{1}$, Huma Qureshi2 ${ }^{*}$, Tayyab Jan', Affan Khan², Muhammad Hadi Abbas², Irfan Maqsood², Shoil \\ Ahmed $^{2}$,M. Qasim ${ }^{2}$ \\ ${ }^{1}$ Department of Plant Pathology, The University of Agriculture, Peshawar-Pakistan \\ ${ }^{2}$ Department of Horticulture, The University of Haripur, Pakistan \\ Corresponding Author email: humaqureshi196@gmail.com
}

\begin{abstract}
This article accomplished the root rot disease of Abelmoschus esculentus (L.) (Okra) pathogen Fusarium solani (F.solani) in vitro with different doses of onion extract as phytobiocide. Diseased samples were collected locally and transferred to the laboratory of the Plant Pathology Department in the University of Agriculture, Peshawar. The F.solani was isolated on Potato Dextrose Agar (PDA) medium, then sub-cultured. The F.solani was tested against various concentrations (5, 10, 15, 20, 25, 30, 35 and 40\%) of onion extract. The results showed that F.solani growth was inhibited slightly at a low concentration of onion extract while significantly reduced by a high concentration.

Keywords: Pathogen, phytoncide, PDA medium, sub-cultured.

\section{Highlights}

- Control of root rot disease of Abelmoschus esculentus

- Fusarium solani was isolated on Potato Dextrose Agar (PDA) medium, then sub-cultured

- A higher concentration of onion extract effectively control the root rot disease of Abelmoschus esculentus
\end{abstract}

\section{Introduction}

Okra (Abelmoschus esculentus (L.) Moench) is one of the most crucial vegetable of Pakistan. It is grown in tropical as well as sub-tropical parts of the world. It is a rich source of calcium, iron, and vitamins A, B, and C (Anon., 2006). Okra is grown twice a year. It is grown on $2.21 \times 105$ hectare with a total production of 2.86×106 tones (Anon., 2006; Kashif et al., 2008).

Okra is attacked by several fungal diseases like Anthracnose (Colletotrichum gloeosporoides), leaf spot (Ascochyta Abelmoschus, Alternaria sp., Cercospora abelmoschus), powdery mildew (Erysiphe cichoracearum), charcoal rot (Macrophomina phaseoli), pod rot (Botrytis sp.), root rot (Rhizoctonia sp., Fusarium sp., Thielaviopsis basicola), stem rot (Sclerotinia sclerotiorum) and wilt (Fusarium oxysporum sp. vasinfectum). The crop is also attacked by different plant viruses viz Tobacco Ring Spot Virus and Yellow Vein Mosaic Virus (Westcott, 1971), also bacterial disease leaf spot (Xanthomonas esculent) (Anonymous, 1997). This crop is also infested by Nematode i-e root-knot nematode (Meloidogyne incognita) (Ehteshamul-Haque et al., 1996; Parveen et al., 1994; Sultana et al., 2005).

Fusarium solani, F. oxysporum, Macroptiomina ptiaseolina, Pytliium butleri, Phytophttiora palmivora, Rhizoctonia solani and $R$. bataticola have been reported to cause root rot of Okra from various parts of the world. Among these, the species of rhizoctonia and fusarium were frequently observed. Root rot of Okra is a commonly encountered disease, seriously affecting the initial plant stand of crop and causing 20-30\% losses (Chauhan et al., 1979). Fusarium root rot is known to decrease both the quantity and quality of major crops, including tomato (Parveen et al., 1993), other vegetables (Ghaffar, 1995), and soybean (Mousa, 1994). The disease is caused by Fusarium solani (Abd-El-Rehim et al., 1992). Its incidence has been reported $10-80 \%$, with a maximum (55-80\%) in plants grown as kitchen/home gardening and minimum (10-45\%) in the crop sown under field conditions. The infected plants are scattered or found in groups when the crop is grown on ridges. Severely infected plants become dead, and their roots turn dark brown (Mithal., 2006; Abbas et al.,2021). The aims and objectives of this study are to use onion extract as Phytobiocid in vitro to control root rot disease of Okra (Abelmoschus esculentus (L.) Moench. For this purpose, the pathogen was isolated, and in vitro trials were measured using organic extracts of onion to control root rot disease.

\section{Materials and methods}

\subsection{Isolation of the pathogen}

The pathogen was isolated from locally collected diseased plants of Okra (Abelmoschus esculentus (L.) Moench during the 2018 growing season of the crop. Seedlings of the crop were cut into small pieces, surface-sterilized $(0.1 \%$ mercuric chloride), and blotted dry, as shown in Fig 1. The treated pieces were placed on PDA medium in Petri dishes under aseptic conditions and incubated at $25{ }^{\circ} \mathrm{C}$. Mycelial growth was developed after some days. The pathogen was identified and purified (Li et al., 2012; de Hoog et al., 2000; Chavan, 2007). 


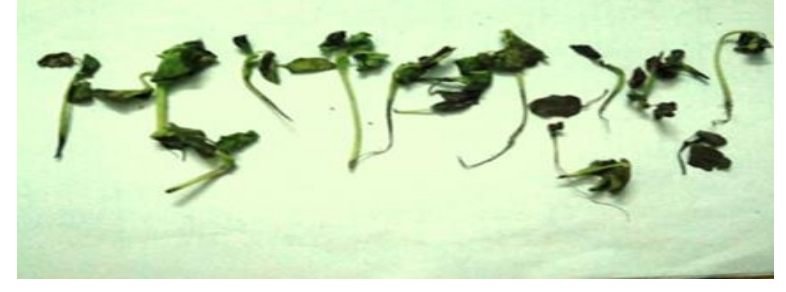

\subsection{In vitro efficacy of onion extracts}

Fig 1. Seedlings of the crop Okra Abelmoschus esculentus

Onion extract was prepared by cutting the onion bulbs into pieces (Fig.2). Different doses of those concentrations were prepared and tested in vitro against the pathogen. The experiment was comprised of the following treatments:

$\mathrm{T} 0=$ Control (only $F$. solani)

$\mathrm{T} 1=$ Onion extract $5 \%(5 \mathrm{~g}$ in $100 \mathrm{ml}$ of SDW) @ $0.25 \mathrm{ml}+F$. solani

$\mathrm{T} 2=$ Onion extract 10\% (10g in 100ml of SDW) @ 0.25 $\mathrm{ml}+F$. solani

$\mathrm{T} 3=$ Onion extract $15 \%(15 \mathrm{~g}$ in $100 \mathrm{ml}$ of SDW $) @ 0.25 \mathrm{ml}+F$. solani

$\mathrm{T} 4=$ Onion extract $20 \%(20 \mathrm{~g}$ in $100 \mathrm{ml}$ of SDW) @ $0.25 \mathrm{ml}+F$. solani

T5= Onion extract $25 \%(25 \mathrm{~g}$ in $100 \mathrm{ml}$ of SDW) @ $0.25 \mathrm{ml}+F$. solani

T6= Onion extract 30\% (30g in 100ml of SDW) @ 0.25ml + F. solani

$\mathrm{T} 7=$ Onion extract $35 \%(35 \mathrm{~g}$ in $100 \mathrm{ml}$ of SDW) @ $0.25 \mathrm{ml}+F$. solani

$\mathrm{T} 8=$ Onion extract $40 \%$ (40g in $100 \mathrm{ml}$ of SDW) @ $0.25 \mathrm{ml}+F$. solani
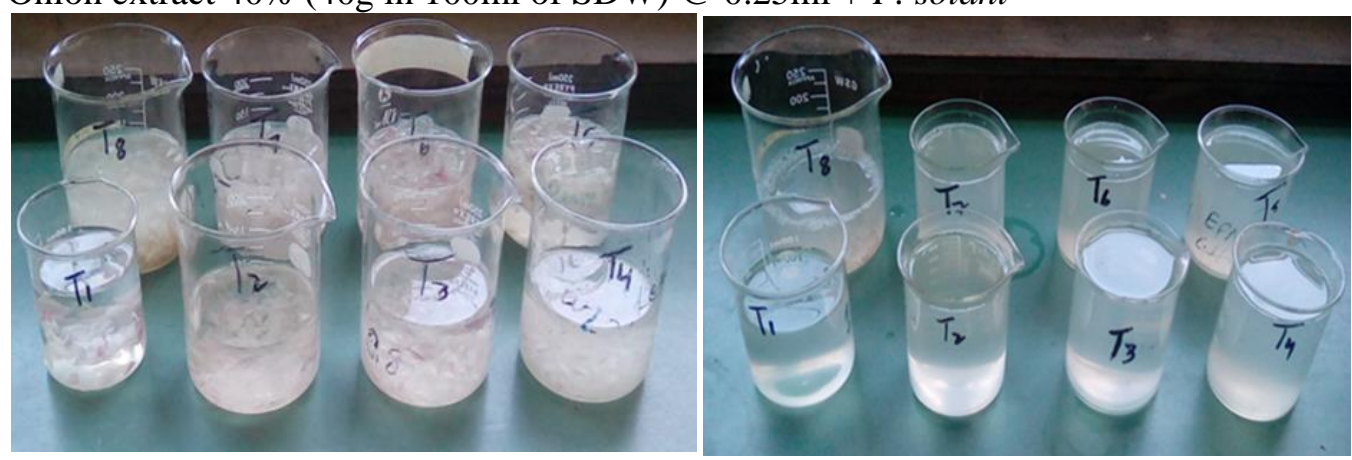

Fig. 2 Preparation of Onion extract

\subsection{Extract Incorporation into medium}

The plant extract was incorporated in the medium before pouring into plates. $F$. solani was inoculated at the center of Petri dishes having PDA medium. Inoculum plugs of uniform size were taken from seven days old culture. The Petri dishes were arranged using four replicates completely Randomized (CR) Design.

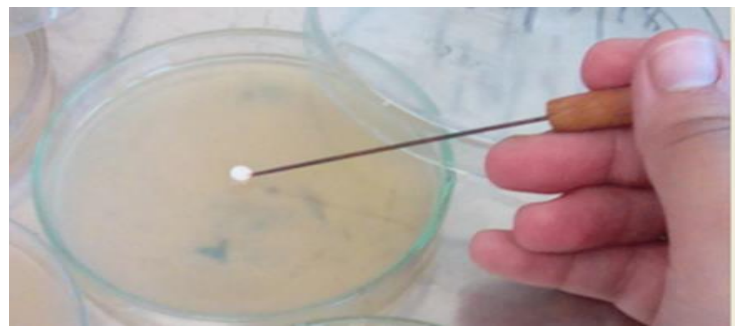

Fig. 3. Inoculation of $F$. solani

\subsection{Identification of the pathogen}

The growth was observed in Petri dishes. The growth was recognized as to be a pathogen inoculum. The pathogen was identified as Fusarium solani by using the key of Barnet and Hunter (1972). The pathogen was separated (Fig.3).

\subsection{Statistical Analysis}

All the recorded data were subjected to statistical analysis using the Analysis of Variance (ANOVA) test, and means were separated using the Least Significant Difference (LSD) test (Dana, 2001).

\section{Result}

\subsection{In vitro efficacy of onion extract against Fusarium solani}


Qureshi et al., 2021

Results showed that the onion extracts significantly reduced the mycelial growth of $F$. solani applied at different concentrations (Table 1), which was higher at increasing the amount of onion extract and significantly reduced the mycelial growth of $F$. solani. The meyclim gwoth shown in Fig 4. with the relation of organic extracts of onion

Table. The colony diameter $(\mathrm{cm})$ of $F$. solani at $25^{\circ} \mathrm{C}$ is affected by different concentrations of onion extract.

\begin{tabular}{|c|c|c|c|c|}
\hline Treatments & $\begin{array}{l}\text { Mean colony } \\
\text { diameter } \\
(21 \text { stMay,2018) }\end{array}$ & $\begin{array}{c}\text { Mean colony } \\
\text { diameter } \\
\left(25^{\text {th }} \text { May,2018) }\right.\end{array}$ & $\begin{array}{c}\text { Mean colony } \\
\text { diameter } \\
\left(29^{\text {th }} \text { May,2018) }\right.\end{array}$ & $\begin{array}{c}\text { Mean colony } \\
\text { diameter } \\
\left(2^{\text {nd } J u n e, 2018) ~}\right.\end{array}$ \\
\hline $\mathrm{T}_{0}$ & $\begin{array}{c}5.88 \mathrm{~A} \\
(---)\end{array}$ & $\begin{array}{c}8.51 \mathrm{~A} \\
(---)\end{array}$ & $\begin{array}{c}9.22 \mathrm{~A} \\
(---)\end{array}$ & $\begin{array}{c}9.27 \mathrm{~A} \\
(---)\end{array}$ \\
\hline $\mathrm{T}_{1}$ & $\begin{array}{c}5.15 \mathrm{~B} \\
(12.41)^{1}\end{array}$ & $\begin{array}{l}8.35 \mathrm{~A} \\
(1.88)^{1}\end{array}$ & $\begin{array}{l}9.07 \mathrm{~B} \\
(1.62)^{1}\end{array}$ & $\begin{array}{l}9.22 \mathrm{~A} \\
(0.53)^{1}\end{array}$ \\
\hline $\mathrm{T}_{2}$ & $\begin{array}{l}4.31 \mathrm{C} \\
(26.70)\end{array}$ & $\begin{array}{c}8.15 \mathrm{AB} \\
(4.23)\end{array}$ & $\begin{array}{l}8.83 \mathrm{C} \\
(4.22)\end{array}$ & $\begin{array}{l}9.03 \mathrm{~B} \\
(2.58)\end{array}$ \\
\hline $\mathrm{T}_{3}$ & $\begin{array}{l}3.93 \mathrm{D} \\
(33.16)\end{array}$ & $\begin{array}{c}7.97 \mathrm{AB} \\
(6.34)\end{array}$ & $\begin{array}{l}8.60 \mathrm{D} \\
(6.72)\end{array}$ & $\begin{array}{l}8.84 \mathrm{C} \\
(4.63)\end{array}$ \\
\hline $\mathrm{T}_{4}$ & $\begin{array}{c}3.77 \mathrm{E} \\
(35.88)\end{array}$ & $\begin{array}{c}7.75 \mathrm{AB} \\
(8.93)\end{array}$ & $\begin{array}{l}8.30 \mathrm{E} \\
(9.97)\end{array}$ & $\begin{array}{l}8.71 \mathrm{D} \\
(6.04)\end{array}$ \\
\hline $\mathrm{T}_{5}$ & $\begin{array}{c}3.36 \mathrm{~F} \\
(42.85)\end{array}$ & $\begin{array}{c}7.58 \mathrm{AB} \\
(10.92)\end{array}$ & $\begin{array}{l}7.98 \mathrm{~F} \\
(13.44)\end{array}$ & $\begin{array}{l}8.53 \mathrm{E} \\
(7.98)\end{array}$ \\
\hline $\mathrm{T}_{6}$ & $\begin{array}{l}2.98 \mathrm{G} \\
(49.31)\end{array}$ & $\begin{array}{c}6.91 \mathrm{BC} \\
(18.80)\end{array}$ & $\begin{array}{l}7.67 \mathrm{G} \\
(16.81)\end{array}$ & $\begin{array}{l}8.20 \mathrm{~F} \\
(11.54)\end{array}$ \\
\hline $\mathrm{T}_{7}$ & $\begin{array}{l}2.65 \mathrm{H} \\
(54.93)\end{array}$ & $\begin{array}{c}5.82 \mathrm{CD} \\
(31.60)\end{array}$ & $\begin{array}{l}7.43 \mathrm{H} \\
(19.41)\end{array}$ & $\begin{array}{l}7.78 \mathrm{G} \\
(16.07)\end{array}$ \\
\hline $\mathrm{T}_{8}$ & $\begin{array}{c}2.20 \mathrm{I} \\
(62.58)\end{array}$ & $\begin{array}{l}5.25 \mathrm{D} \\
(38.30)\end{array}$ & $\begin{array}{c}7.16 \mathrm{I} \\
(22.34)\end{array}$ & $\begin{array}{l}7.78 \mathrm{H} \\
(16.07)\end{array}$ \\
\hline Mean & 3.80 & 7.36 & 8.25 & 8.57 \\
\hline $\mathrm{CV}(\%)$ & 2.75 & 2.52 & 0.95 & 0.75 \\
\hline LSD value & 0.15 & 1.40 & 0.11 & 0.09 \\
\hline
\end{tabular}

$\mathrm{Cv}$ 0.95-2.75 and LSD values 0.15-1.40

\section{Discussion}

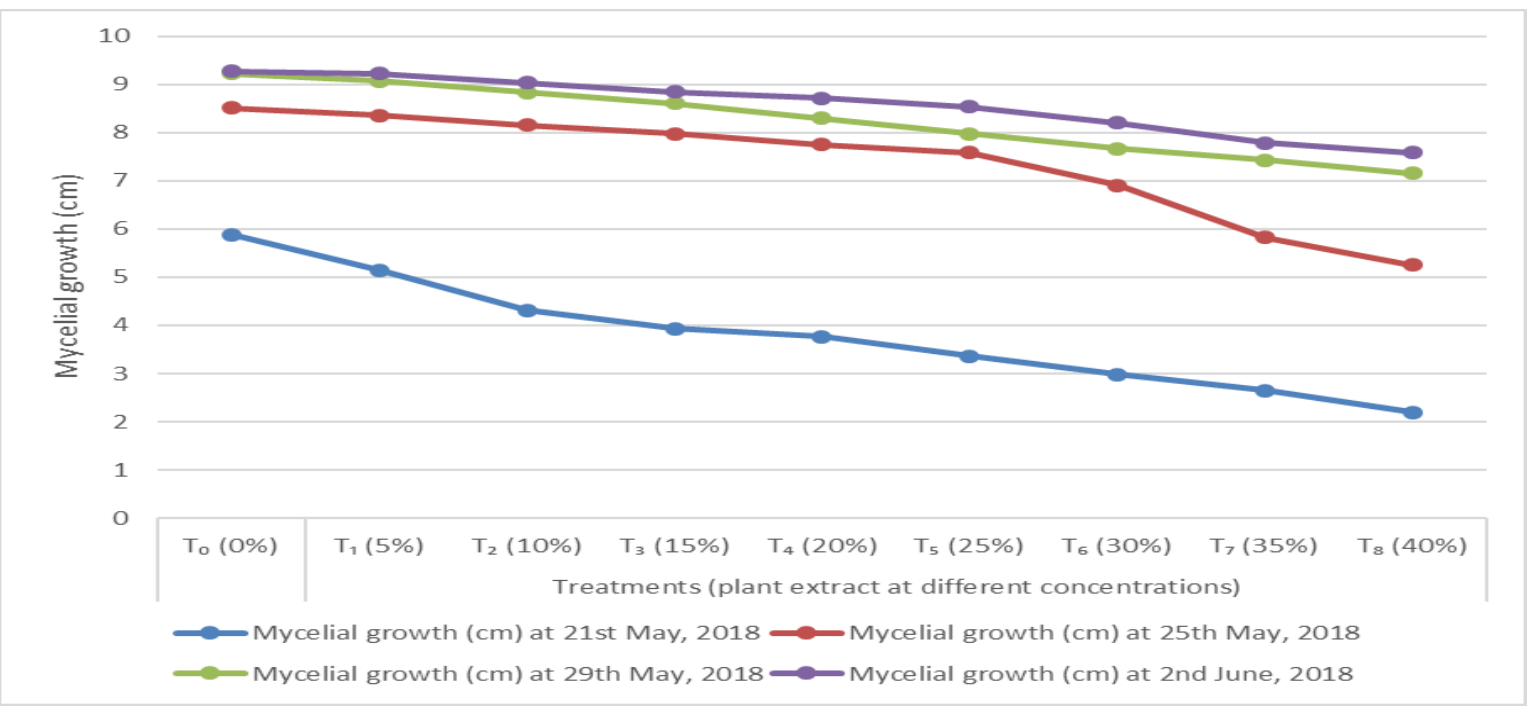

Fig. 4. Mycelial growth with interaction of tratemtns

Okra is susceptible to the attack of several soils borne fungi. Fusarium solani is one of them severely destructive to the okra crop. The attack is mainly at the seedling stage (Abd-El-Rehim et al., 1992; Godoy et al., 1990; Kamlesh et al., 1998; Chohan and Singh, 1972). Okra is a summer vegetable, and the pathogen also favours high soil temperature. F. solani is 
adaptable to various environmental conditions due to which high variation exists among the isolates (Thamburaj Singh, 2001). After three days of incubation, the mycelial growth was 2.20 to $5.15 \mathrm{~cm}$ at different concentrations of onion extract. This inhibition was 12.41 to $62.58 \%$ as compared to control. After six days in the incubator, the onion extract reduced the mycelial growth by 1.88 to $38.30 \%$. Similarly, this mycelial growth inhibition was 1.62 to 22.34 and 0.53 to $16.07 \%$ after nine and twelve days of incubation, respectively.

The result of this study suggests that onion extracts significantly reduced the mycelial growth of $F$. solani at different concentrations. Therefore, onion extract can be commercialized and used against many fungal pathogens. Similar results of plant extracts were also obtained by other scientists (León et al., 2014; Dellavalle et al., 2011; Patel et al., 2010). They observed that applied turmeric rhizomes extract reduced F.solani. Kapadiya et al., (2014) found that turmeric rhizome extract had the highest mean suppression, trailed by jatropha leaf extract and neem leaves extract.

\section{Conclusion}

The onion extract was used as a Phyto biocide to reduce the mycelial growth in-vitro at different concentrations. This reduction was 0.53 to $62.58 \%$. The data found that low levels of onion extract suppressed $F$. solani development modestly, but high concentrations massively diminished it. Detailed research work is needed to manage the phytobiocidal Fusarium root rot of Okra, including testing other botanicals for its management.

\section{Conflict of interest}

The authors reported no potential conflict of interest

\section{Acknowledgment}

The authors highly acknowledged the laboratory Department of Plant Pathology, The University of Agriculture, PeshawarPakistan

\section{References}

Abbas, A., Zulfiqar, A., Ahmad, M.I., Tahir, M.A., Shah A.N. (2021) The influence of fungicides and growth media on the morphological and physio- biochemical parameters of Citrus rootstocks. Journal advances of Nutrition ascience and technology 1(3): 136-144.

Abd-El-Rehim, M. A., Darweish, A. K., Tarabeih, A. M., \& Hassan, A. A. M. (1992). Damping-off and root rot of okra and table beet with reference to chemical control. Assiut Journal of Agricultural Sciences (Egypt). 23:19-36.

Anonymous. (1997). Handbook of Agriculture. Fifth Edition. Indian Council of Agricultural Research, New Delhi, 371.

Barnett, H. L., \& Hunter, B. B. (1972). Illustrated General of Imperfect Fungi. 3rd (ed.) Burgess Publishing Co. Minneapolis. pp241.

Chauhan, M. S., Tripathi, N. N., Duhan, J. C., \& Virk, K. S. (1979). Rhizoctonia root rot of Okra and its control. Pesticides. 13: $24-25$.

Chavan, S. S. (2007). Studies on fungal diseases of patchouli with special reference to wilt caused by Fusarium solani (Mart.) Sacc (Doctoral dissertation, UAS, Dharwad). University of Agriculture Sci. Dhaward. pp. 1-98, (2007)

Chohan, J. S., \& Singh, I. Q. B. A. L. (1973). Two new fungi associated with root rot and wilt of bhindi (Abelmoschus esculentus) in India. Indian journal of mycology and plant pathology.

Dana, S. D. (2001). Statistical and data analysis for the behavioral sciences. Von Hoffmann press, Inc. New York. USA, $11,411-454$.

de Hoog, G. S., Guarro, J., Gené, J., \& Figueras, M. J. (2000). Atlas of clinical fungi (No. Ed. 2). Centraalbureau voor Schimmelcultures (CBS).

Dellavalle, P. D., Cabrera, A., Alem, D., Larrañaga, P., Ferreira, F., \& Dalla Rizza, M. (2011). Antifungal activity of medicinal plant extracts against phytopathogenic fungus Alternaria spp. Chilean journal of agricultural research, 71(2), 231. Patel, N. N., Joshi, K. R., Patel, P. M., Patel, M. R., \& Patel, R. M. (2010). Bio-efficacy of plant extracts against Fusarium solani. International Journal of Plant Protection, 3(2), 306-308.

Ehteshamul-Haque, S., Abid, M., Sultana, V., Ara, J., \& Ghaffar, A. (1996). Use of organic amendments on the efficacy of biocontrol agents in the control of root rot and root knot disease complex of Okra. Nematol. medit, 24, 13-16.

Ghaffar, A. (1995). Biological control of root rot and root knot disease complex of vegetables. PAEC Research project final research report Department of Botany, University of Karachi, Karachi-75270, Pakistan, 98.

Godoy Angulo, T. P., Zavaleta-Mejía, E., Ramero Cova, S., Gómez Aguilar, J. R., \& Rodríguez Mejía, M. D. L. (1990). Aetiology of okra (Hibiscus esculentus L.) root rot in Iguala, Guerrero. Revista Mexicana de Fitopatología, 8(2), 107114.

Kamlesh, M., \& Shekhawat, K. S. (1988). A new species of Fusarium causing root rot in Okra. Vegetable Science, 15(2), 196-197. 
Kapadiya, I. B., Undhad, S. V., Talaviya, J. R., \& Siddhapara, M. R. (2014). Evaluation of phytoextracts against Fusarium solani causing root rot of Okra. Journal of Biopesticides, 7, 7.

Kashif, S., Yaseen, M., Arshad, M. U. H. A. M. M. A. D., \& Ayub, M. (2008). Response of Okra (Hibiscus esculentus L.) to soil given encapsulated calcium carbide. Pakistan journal of Botany, 40(1), 175.

León, L. D., Karla, I., Ramírez-Mares, M. V., Sánchez-López, V., Ramírez-Lepe, M., Salas-Coronado, R., ... \& HernándezCarlos, B. (2014). Effect of crude plant extracts from some Oaxacan flora on two deleterious fungal phytopathogens and extract compatibility with a biofertilizer strain. Frontiers in microbiology, 5, 383.

Li, D. H., Wang, L. H., Zhang, Y. X., Lv, H. X., Qi, X. Q., Wei, W. L., \& Zhang, X. R. (2012). Pathogenic variation and molecular characterization of Fusarium species isolated from wilted sesame in China. African Journal of Microbiology Research, 6(1), 149-154.

Mithal, M. J. (2006). Low cost and pollution free technology against root rot of Okra. Pakistan com.

Mousa-E, S. M. (1991, December). Biological management of soil-borne pathogens and root-knot nematode complexes on soybean. In Proc. Second Afro-Asian Nematol. Symp. at Menoufiya Egypt 18-22 Dec (pp. 110-114).

Parveen, S. H. A. H. I. D. A., Ehteshamul-Haque, S., \& Ghaffar, A. (1993). Biological control of Meloidogyne javanica on tomato and Okra in soil infested with Fusarium oxysporum. Pak. J. Nematol, 11(2), 151-156.

Perveen, S. H. A. H. I. D. A., Ehteshamul-Haque, S., \& Ghaffar, A. B. D. U. L. (1994). Biological control of soilborne root infecting fungi in tomato and Okra. Pakistan journal of Botany, 26, 181-181.

Sultana, V., Ehteshamul-Haque, S., Ara, J., \& Athar, M. (2005). Comparative efficacy of brown, green and red seaweeds in the control of root infecting fungi and Okra. International Journal of Environmental Science \& Technology, 2(2), 129-132.

Thamburaj, S., \& Singh, N. (2001). Vegetables, tubercrops, and spices, pp 234.

Westcott, C. (1971). Plant Diseases Handbook -3d ed- New York: Van Nostland Reinhold, p 833. 